\title{
Using the Flipped Classroom Model in the Development of Basic Language Skills and Enriching Activities: Digital Stories and Games ${ }^{1}$
}

\section{Pinar Girmen}

Assoc. Prof., Eskisehir Osmangazi University, Primary School Education, Eskişehir, Turkey,pgirmen@gmail.com

\section{Mehmet Fatih Kaya}

Dr., Eskisehir Osmangazi University, Primary School Education, Eskişehir, Turkey, mfatihkaya11@gmail.com

\begin{abstract}
The purpose of this research is to enrich the process of developing the basic language skills of 4th grade students with digital story activities and games based on the Flipped Classroom Model (FCM). This study was conducted with 4th grade students in a Turkish course. It was based on action research. The Turkish courses were prepared according to the FCM. The aim was to develop basic language skills of the students with various activities. This study focused on digital story and games. For the digital story activity, the students prepared some scenes of the text they wrote with play dough, took pictures and recorded their voices by reading the text aloud. After that, they sent them to the researcher via WhatsApp. After gathering the material, digital stories were converted into a video. Before the game based activities, some texts and grammar topics were presented to the students. Then, some games were played in the classroom to reinforce the newly acquired knowledge. In conclusion, with the use of FCM, by enriching with digital story and game-based activities teaching-learning processes in Turkish courses, the development of students in many areas, firstly basic language skills, then cognitive, emotional, social and psychomotor skills were contributed.
\end{abstract}

Keywords: Flipped Classroom Model, digital storytelling, gamification, basic language skills, ICT integration, primary school education

\footnotetext{
1 The study is a part of a doctoral dissertation of "Mehmet Fatih Kaya" titled "Implementing Flipped Classroom Model in Developing Basic Language Arts of 4th Grade Students", and supported by Eskisehir Osmangazi University Scientific Research Projects Commission coded as "201621A211".

Citation: Girmen, P., \& Kaya, M. F. (2019). Using the Flipped Classroom Model in the Development of Basic Language Skills and Enriching Activities: Digital Stories and Games. International Journal of Instruction, 12(1), 555-572. https://doi.org/10.29333/iji.2019.12136a
} 


\section{INTRODUCTION}

The development of digital technologies in terms of speed and diversity has significantly influenced the educational process. By changing teaching-learning process, the students moved out to an independent learning environment, without time and space limit. New technological developments make information spreading, access to information, doing homework, studying, watching video lectures possible in every place with every device. This situation also changes the learning habits of the new generation learners. According to this, it can be said that learners are prone to more active, vibrant, energetic, colorful and interactive teaching-learning environments without the time and space limit. In the education, the learning structures that the students can reach and intervene to the content individually and learn these contents according to his/her pace in- or out-of-class come into prominence (Bishop \& Verleger, 2013; Oral, 2005). For that reason, new learning approaches and models have emerged to address the need mentioned above. FCM is one of the models that combines both in-class and out-of-class learning processes systematically and complementarily with technology support.

\section{Literature Review}

The Flipped Classroom Model (FCM) is based on that traditional classroom activities are held at home and traditional home activities are held at school. According to the model, the teacher prepares the materials. The students follow the e-contents of the topic at home, they take notes, prepare questions, complete the activities. Then, they participate in the planned activities at school (Bergmann \& Sams, 2012). Activities based on a variety of e-learning content, such as videos, visuals, audio and texts prepared by the teacher can be presented to the students on various online or offline platforms. Students complete tasks related to these contents regardless of time and place. Therefore, there is a considerable time gap in the classroom and the teacher can plan various activities and games to practice.

The FCM has advantages such as supporting student-centered education by considering individual differences, creating an efficient, active and highly interactive learning environment with the activities and practices both inside and outside the classroom. It also helps in supporting and integrating students who do not or cannot attend due to various reasons to the teaching-learning process (Bergmann \& Sams, 2012, 2014; Fulton, 2012; Herreid \& Schiller, 2013; Karadeniz, 2015; LaFee, 2013; Prashar, 2015). In the 21 st century, especially making classroom management more flexible and transparent, making lessons more fun, effective and creative is useful for getting teaching-learning process affective. The teacher is in the role of a mentor. He is taking care of students in individual and group work, being able to closely follow the learning processes of students with and without special needs related to learning, improving teacher-student-parent interaction, developing cooperative working skills and being able to follow students outside the classroom (Ayçiçek \& Yanpar Yelken, 2018; Bergmann \& Sams, 2012, 2014; Cabi, 2018; Fulton, 2012; Herreid \& Schiller, 2013; Karadeniz, 2015; LaFee, 2013; Prashar, 2015; Tütüncü \& Aksu, 2018; Urfa, 2018). Some disadvantages such as requiring more effort and expertise in some aspects (preparing econtent and expertness in a subject), taking precautions for student participation and 
follow-up, possible problems with technological equipment (deficiency, malfunction, cost etc.), the level of digital literacy and technopedagogy not being sufficient are also mentioned (Bergmann \& Sams, 2012; Gençer, Gürbulak \& Adigüzel, 2014; Karadeniz, 2015). However, even though these limitations seem to be a burden at first sight in terms of time and money, they can be quite economical in medium and long term.

The skill-based structure of Turkish course partially changes the implementation of FCM. Turkish courses - as mother tongue- consist of some studies on relevant language skills, vocabulary, and also instructing grammar -based on grade-. According to this, it is preferred that the process should be intensely based on developing language skills, and contain a small amount of grammar at the primary school level. In terms of FCM, it may be appropriate to carry out reading and listening comprehension of text studies at home, and to carry out studies based on speaking and writing skills in-classroom. Besides, checking the participation of the students and the understanding of the subject/text or etc. by the teacher before coming to class (Bergmann \& Sams, 2012, 2014) can contribute to the process of Turkish instruction. In this way, it can be said that in-class time may be broadened considerably. In this way, in-depth studies can be carried out for speaking and writing skills which are not sufficiently emphasized before (Pasisis, 2015). In this context, that's why the Turkish instruction process that is not a one-dimensional knowledge and skill area, but multi-faceted and has intricate activities (Sever, 2011); the use of texts that could improve the language taste and consciousness of the students with their original forms exceeds the in-class period and requires the use of out-of-class time. Also some time-consuming activities such as group work, games, theatrical activities, visual and auditory activities, and interdisciplinary activities can be conducted (Güneş, 2012). Therefore, there is a need for models that combine the inclass and out-of-class processes effectively in Turkish instruction -and the development of the basic language skills- process. In this respect, the FCM -because of its naturecarries potential implementation area in Turkish courses -as mother tongue-.

In the literature of language education using FCM, researches focus mostly on teaching a language as a foreign language (Başal, 2012; Ekmekçi, 2017; Hung, 2015; Temizyürek \& Ünlü, 2015). However, it can be said that there are few researches on mother language skills (Cockrum, 2017; Moran, 2014, 2018). According to the researches, FCM generally plays a role on developing language skills (Basal, 2015).

The use of FCM has many opportunities implementation of student-centered and active learning activities. Creating digital story and game-based activities can be used in FCM process. A digital story is an artistic, creative and at the same time aesthetic product created in a digital format using the possibilities of multimedia tools of a story (Sawyer $\&$ Wills, 2011). Digital stories spread along with the technological advancements and have had their own unique features, they have been used effectively in different teaching-learning processes and during lessons closely related to language skills (Dupain \& Maguire, 2005; Meadows, 2003; Smeda, Dakich \& Sharda, 2012). While the digital stories are used for teaching content by teachers in the education process, they can be used by students during individual learning or digital story preparation. This allows students to participate and reflect what they learn in a creative way (Matthews, 
2008). Also, as digital stories develop effective and profound learning, it facilitates the use of student-centered strategies, student participation, reflection of learning, projectbased learning and effective technology integration (Barrett, 2005).

Games are important tools that people have used for different purposes at every stage of their life. The recently emerging concept of gamification describes motivating participants through the addition of game elements and mechanics to activities including no games, thereby increasing the participation and making that activity fun and productive (Sarıtaş \& Yıldız, 2015, Seaborn \& Fels, 2015). Designing a game with a topic that is planned to be learned in the form of simple explanation or homework will positively affect the participants' desire for participation, interest, attitudes, motivation and success (Di Bitonto et. al., 2014; Muntean, 2011; Su \& Cheng, 2015).

\section{The purpose of the study}

The purpose of the research is to describe the process of creating digital story and gamebased activities to enrich the development of basic language skills of fourth graders in primary school during the Turkish course based on FCM. In this study; it is thought that students will be able to improve their basic language, digital skills and the prejudices of the families related to technology integration will be eliminated thanks to the combination of in-class and out-of-class learning environments. Besides, the research will give us a point of view on how to apply technology integration, the FCM and what we should be careful about at a school or in a classroom where students with normal development, learning disabilities, ADHD (attention deficit hyperactivity disorder), superior abilities and inclusive students are educated together. In this context, the study searches for answers to these questions:

What are the situations related to the implementation of the model in the process of developing the basic language skills of the students in the fourth grade Turkish course that uses the Flipped Classroom Model?

What is the students' and parents' views on the activities?

\section{METHOD}

The study is conducted as an action research. Action research is based on philosophically critical theory. According to this, the theory criticizes the philosophical bases of both quantitative and qualitative approaches, and gives a different perspective to educational researches. The main purpose of critical theory is to understand and change the behaviors and thoughts of the participants (Ekiz, 2009). For this purpose, action research is seen as a different research process. The action research is defined as a systematic research (Mills, 2003) conducted by teachers, school principals, school counselors or other members of the teaching and learning environment about how the school works, how students are taught, and how they can learn better. The study aimed at defining and describing situations that are experienced in the preparation of a digital story and game-based activities. It focuses on enriching the process of the basic language skills development of fourth graders in Turkish courses with the activities of 
the FCM and suggesting solutions to solve the problems and deficiencies that may occur.

\section{Participants}

Participants of the research consisted of 23 students, 11 male and 12 female students, who study in $4 / \mathrm{C}$ class in a state primary school in Eskişehir and their parents. While determining the participants, criterion sampling, a type of purposive sampling, was used. Criterion sampling is based on focusing on every situation, including a variety of predetermined criteria (Yıldırım \& Şimşek, 2008). The criterias of this study are the presence of at least one device out of desktops, laptops, tablets or smartphones at the students' houses, and the availability of wired, wireless or mobile internet access. Most of the students are from a middle and upper-middle socioeconomic level. A male student in the class has ADHD. According to the classroom teacher, one male student does not have the same development level and characteristics because he is younger than the others and two female students have learning disabilities.

\section{Credibility and transferability}

Credibility in qualitative research (accuracy, consistency, validity) means observing and transferring data without changing or as neutrally as possible in the course of the research (Kirk \& Miller, 1986). Transferability (reliability, verifiability, repeatability) does not mean the findings and conclusions can be generalized about other situations but it means similar situations may occur again (Yıldırım \& Şimşek, 2008). Necessary permissions were taken from institutions, students, teachers and parents for this research. The views of the validation committee and experts on the appropriateness of action plans, interview forms, e-learning contents and materials were taken and arrangements were made according to the suggestions. During the research, data was gathered from different sources; data diversity and diversity in research were provided by researchers analyzing the data separately. After presenting the data to the validation committee that comes together at regular intervals, expert opinions were also collected. Thus, the research was proven to be reliable. Detailed descriptions and direct citations are provided in the presentation of findings regarding the transferability of the reader's ability to visualize the research context in his mind. Therefore, it can be said that the results of this research can be suitable to classes with the same or better conditions.

\section{Data collection}

Action research is a process-based method that requires a lot of time to collect data on a problem in its own environment, and multiple data collection methods (Yildirım \& Şimşek, 2008). Therefore, in this study, in order to examine the process deeply, different data collection tools were used. The implementation process was carried out by the researcher during the fall semester of the 2016-2017 academic year. The digital story activity took two hours; and in different weeks three game-based activities took totally 9 hours (three hours each one), in the classroom. The datas collected via observation notes, student and researcher diaries, semi-structured interviews with students and parents and student products (writing, digital stories, visuals etc.). Also, students' opinions about the texts and their opinions about the activities were collected at home. 
During the research, the researcher developed two-dimensional action plans, learning materials and e-learning contents in accordance with the FCM to be used in and out of class. The prepared action plans and interview forms were submitted to the validation committee, the opinions of the experts were collected and necessary arrangements were made according to the feedbacks.

\section{Data analysis}

While data were collected on the one hand during the research process, on the other hand macro analyzes of the data were made. In every activity, the data as video recordings, diaries, and student products were individually cataloged in a digital environment. The student products were photographed, then converted to digital format and finally made available for analysis. After the data collection phase was completed, micro analyzes were performed.

The data collected (video recordings, diaries and student products) in the study were subjected to descriptive analysis. In descriptive analysis, the data is summarized and interpreted according to predetermined themes. In this study, basic language skills and sub-skills are considered as a category and code. As a result of the analysis, the relevant data are classified according to these categories and codes. The data parents' and students' view was subjected to content analysis. In content analysis categories and codes determined after analyzing the views. In the presentation of the findings, direct quotations are included.

\section{FINDINGS}

Findings from the activities were presented in this section.

\section{Digital Story Activity}

Rikitiki Tembo story (Oral, 2014) about "bragging, looking down and modesty" has been used as a listening text by being divided into two sections in a way that it would be exciting and intriguing during preparing a digital story. Students were asked to listen to the second part of the text on the website at home. In the classroom, after discussing about the text, a worksheet related to the story items and the content from the listened part was completed. In the second lesson, students were asked to guess what would happen in the first part of the text and to write their predictions. Then, they were asked to prepare a few scenes regarding their predictions about the first part in their houses with the playdoughs given by the researcher and to send those documents to the researcher via WhatsApp. Students were given four days, including the weekend to complete the task. Since all students do not have the device, software, internet connection and techno-pedagogical competence, the simplest way was to choose the WhatsApp application. The researcher combined the visuals and audio texts sent by the students into a digital story.

According to the findings of the study, most of the students sent their digital stories as visuals and voice recordings. In addition, it appears that students who prepared visuals but did not send voice recordings prepared one or more visuals. The fact that those students did not send a voice recording can be interpreted as that they did not fully 
understand the instructions. Table 1 includes the durations, numbers of the scenes and visuals of the digital stories that students prepared.

Table 1

The durations, number of the scenes and visuals of the digital stories

\begin{tabular}{lccc|lccc}
\hline Student & Scene(s) & Visual(s) & Time $(\mathrm{sec})$ & Student & Scene(s) & Visual(s) & Time (sec) \\
\hline Tarı & 9 & 9 & 155 & Kayra & 3 & 3 & - \\
\hline Emre & 12 & 12 & 169 & Ayça & 2 & 2 & - \\
\hline Yeşim & 4 & 4 & 70 & Dilek & 4 & 1 & - \\
\hline Elçin & 3 & 3 & 90 & Arda & 3 & 3 & - \\
\hline Nevin & 1 & 1 & 40 & Emel & 1 & 1 & - \\
\hline Beren & 17 & 17 & 77 & Ecrin & 5 & 5 & - \\
\hline Eda & 9 & 9 & 138 & Nihal & 1 & 1 & - \\
\hline Batuhan & 8 & 1 & 44 & Gökalp & 1 & 3 & - \\
\hline Metin & 6 & 6 & 130 & Kemal & 3 & 3 & - \\
\hline Erhan & 4 & 4 & 116 & Güray & 1 & & - \\
\hline Asli & 4 & 4 & 65 & & & & \\
\hline Sümeyra & 1 & 1 & 140 & & & & \\
\hline
\end{tabular}

While most of the texts were related to the topic, others were partially or completely irrelevant to the topic. The deficiencies, which occurred because it was the students' first time to come across such an activity and the instructions were not understood, can be accepted.

In this activity, there is a variety of development in students according to observation, researcher's diary, findings obtained from students and parents' opinions. According to it, it can be said that the listening, writing, visual literacy, imagination, technology literacy, social, effective communication and motor skills of the students who participated in in-class, out-of-class activities and had fun while learning were supported. Here are some examples from parents' comments:

Ecrin: I used to find studying Turkish with the help of technology was strange. After a few attempts, my child started practicing without any help from us. Despite the difficulties we had with motor skills, the digital story made her very happy.

Yeșim: When she tried to animate the story with visuals, she did it in such a way that what they did up to now is nothing compared to that. So watching and visualizing support motor skills.

Gökalp: He is looking forward to studying. He loves the activities and wants to finish them without losing time. Thanks to the activities, he does not forget what he normally forgets. While he studies, I go to check up on him to see if he is studying or not, every time I find her studying.

Here are some examples from students' comments:

Nihal: It improves our intelligence. I use my imagination; my imagination is improving. My thoughts have increased. I did not share my stuff before, but I have decided to share it now. Because I have improved myself with the activities.

Tarık: It was great and fun. While learning, I had fun. It is very good when you do both. It is more effective.

Yeșim: My family loved it very much and said it was very nice. Sometimes, I do the listening parts with my mom. She also likes them, like me. She said that they were fun and wants to thank you for them. 
Arda: I learned, had fun and became happy. I was happy to be able to participate in the activities in the classroom.

Disadvantaged students compared to others had significant improvement. Tarık, who exhibited problematic and disinterested behavior in previous activities, created a digital story in the form of nine visuals and a two-minute long video; Asl,, who was distracted, had trouble with focusing, and was behind during some activities, created a digital story longer than a minute with four visuals. This can be considered as improvement. Nevin, who especially had more disadvantages than others, did not participate in activities, did not raise her hands, sent a digital storyline as a video with a text of not very high quality. This can be considered as an indicator that the activity is appropriate for students at all levels. Here are some examples of students' digital stories:

- Product 1 (Metin): Once upon a time, there were three friends. One day, Rikitiki suggested going to the well: 'Friends, should we go to the well? Simon was grounded and a little sick, so his mom did not let him go. However, Joe listened to his brother even though he did not want to. He did not know why he did so. They went to the nearest well but it was very dangerous. Rikitiki said;
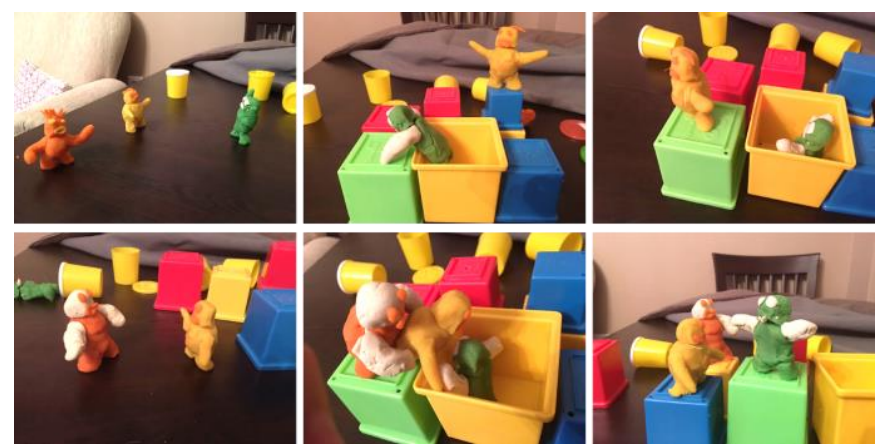

'Come on let us go to the other well, it is more fun.' Joe said: 'No, it is more dangerous. This one is deep enough.' Rikitiki was showing off by saying 'Are you afraid?'. Joe said, 'Don't bring this topic up again, I won't go there". At the end, Rikitiki convinced Joe and they went to the distant well. Rikitiki insisted saying 'Come on let's look at it, come please.' That is why Joe was looking down. Then, he fell down. He held onto a branch. However, the branch broke. Fortunately, he was not injured. The well was almost dry. Because Rikitiki knew that would happen, he was trying to kill time by playing with a broken nail. However, when he saw Joe falling down, he went to Uncle Ironmonger. He took a rope from him and Uncle Ironmonger and he pulled Joe up. Joe was not aware of what was happening but he was very afraid. He thanked Rikitiki for helping him.
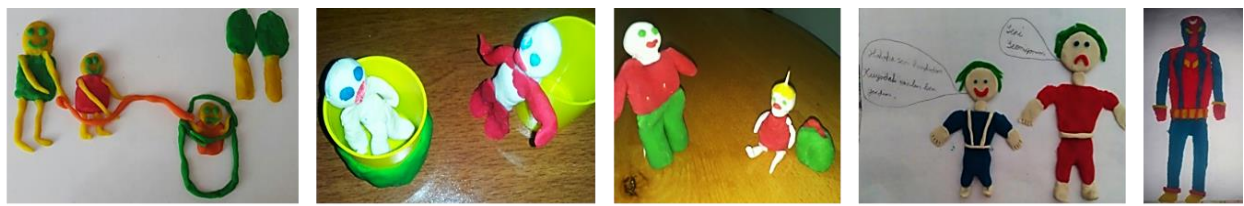

- Examples of some visuals without voice recordings (Respectively; Kayra, Ecrin, Ayça, Kemal, Gökalp):

\section{Game-Based Activities}

In this study, students played straw game, jenga and golf individually or as a group.

\section{The straw game}

The straw game is a race that students play to take candies from one place to another with straws in their mouths. The student who comes first gets a point if he knows the 
answer of the question he is asked. If he does not know, the same question is asked to another student; if he knows the answer, he gets the point. The game can be played individually or as a group; as for this study, it was played individually. Among the words they learnt in the previous three texts, the students were asked about the meanings of the words, phrases or how they were used (original meaning, a metaphor, in an idiom, etc.). The game took three hours so that each student could play. The researcher tried to discuss each answer given by the student with the whole class. Therefore, students were still learning while answering the questions and listening to others' answers. It was observed that students could not stop smiling and having fun from the moment, they learnt that they would play a game onwards. The researcher wrote the following in his diary (RD1):

"When I told them that we would play a game today, they became very happy. They almost never sat down; they always supported their friends during the game. They were very excited."

\section{Jenga}

In this activity, the punctuation marks were prepared in the form of a video lecture by the researcher and presented to the students on the internet. Then, for the purpose of reinforcement, comprehension and practice, the students played Jenga for three hours in the classroom. During the game, the desks were put in ' $U$ ' shape, Jenga blocks were put in the middle. Sentences without punctuation marks were written on the board. In one minute, in turns students were asked which punctuation mark is appropriate. Students were asked the reason of their answers. The whole class had a discussion. Then, the students removed two blocks from the Jenga tower. At the end of the game, students were not ordered in terms of success, and no prize or reinforcement was provided.

This activity was addressed to -a part of grammar lesson- punctuation marks. During highly interactive activity processes such as this one, students completed the relevant elearning content at home and they repeated it during the in-class game. In addition to that, they tried to explain their answers, tried to understand each other's answers and their reasons. In addition, during this process, the researcher tried to encourage students to question, reason and express their thoughts by asking students the reasons of their answers. As a result, the game was actively engaging and interactive, it helped students comprehend the topic as much as possible. The following conversation took place during

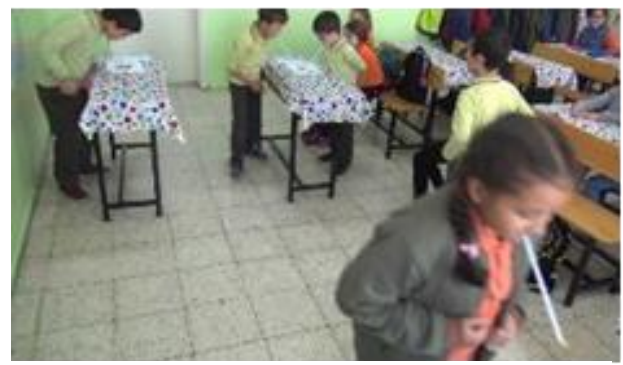

Picture 1. Taken during the Straw game the game (V1, 02.05): 
(Many students are raising their hands.)

Emre: The first one should be dot.

Researcher: (To the other students) Colon or dot?

Most students: Colon.

Researcher: Why?

Tark: It shows what those three titles are.

Elçin: Isn't it supposed to be semicolon?

Researcher: Why?

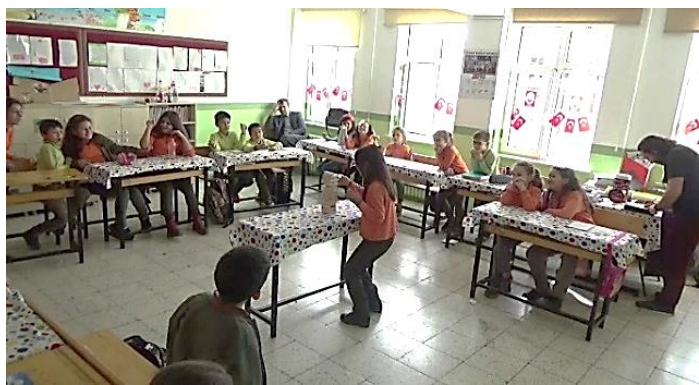

Picture 2. Taken during Jenga

Elçin: Because those three titles are ordered respectively.

Tarık: No, we should use semicolon to connect two sentences.

Researcher: Does anyone have another opinion?

Ecrin: It is stated that there are three titles. It is supposed to be semicolon.

Most students: Correct.

Researcher: Why?

Kayra: Because it connects two sentences.

Researcher: No.

Tarık: Because similar things were used.

Researcher: Yes, correct. For the last one, Ozan said it should be 'dot'. Is it correct?

Most students: Correct.

Researcher: Why?

Emre: It is the end of the sentence.

Researcher: Yes, correct. What would happen if there were many titles instead of three titles?

Most students: It would be 'Ellipsis'.

Researcher: Yes, exactly, thank you...

Although this activity is not based on competition, reward, winning or losing, the students' attendance, attention and motivation were significant. According to this, depending on the age group and developmental period of the students, it can be said that the lessons can be enjoyable and productive with small changes in the teaching-learning process. About the activity, the researcher wrote the following in his diary (RD2):

"There was no competition or winning during the game today. Jenga tower collapsing or standing straight did not mean anything in the game. However, small changes and the game motivated them very much and they comprehended the topic very well. This was our second game and I can say that the culture of playing games and working as groups is forming. As the culture is forming, it is starting to have its own dynamics. Class management is easier; problems such as making noise during games or activities, interrupting others and interfering with the person answering are much less now. So, I am also pleased with the process, just like students." 


\section{Golf}

This activity is designed to develop the students' skills on the main idea, the topic and $5 \mathrm{~W} \& 1 \mathrm{H}$ (Who, What, Why, When, Where and How) that constitute the basis of sentences, paragraphs and text comprehension. The video lectures prepared by the researcher related to the topics were uploaded on the internet. Then, students played golf for 3 hours for the reinforcement, comprehension and practice of the topic. For the game, the researcher brought a golf club, cut holes on a box in three different sizes and wrote points above them. The students were divided into six groups of four. Groups were asked to answer the questions on the board and they were ranked according to correct/incorrect answers given to the questions. Whether the answers given to the questions were correct or not, each student in the group was given a chance to hit the ball and to gain points according to the hole the ball went through. Within three hours, each group answered three questions and hit the ball.

The important part of the FCM in terms of game-based activities is that, like previous games, the mistakes are corrected with the teacher and students are given feedbacks right away. Although a group of students responds to a question during the game, the fact that everyone focuses on the question at the same time is important for the students to test themselves and follow the process. In addition, when the group gave their answer, the researcher asked everyone whether it was correct or not and why. Then, he gave feedback to reinforce students' thinking and learning. Here is an example (V2, 01.10.34): A question about the topic of the text was asked and the answer of the group was 'Positive and negative aspects of communication'.

Researcher: Do you think the answer is correct?

(Students are raising their hands)

Eda: Here it does not say communication can be positive if it is used this way or it can be negative if it is used that way.

Researcher: Thank you. Does anyone want to answer another question?

Kayra: I think it is the main instruments of

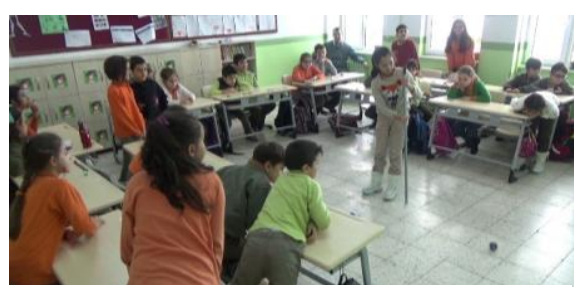

Picture 3. Taken during playing golf

communication. It says, for example, we can make phone calls, send a telegram and write letters.

Erhan: I think it is talking about what the communication is.

Researcher: Thank you. Pay attention to this sentence: "The things we do mutually are communication." Therefore, that is our answer.

The level of participation of the observed students was high. Ozan, who had more disadvantages than the others did, always raised his hand to speak. The researcher, who saw this as an opportunity, tried to encourage him to speak as much as possible. Regardless of whether students were right or wrong, class participation was observed to be high. Besides, it can be said that students were focused on the questions, they were not busy with something else, the noise and problems were less, their attention and motivation were higher. The researcher observed that the groups worked calmly, in 
peace and harmony, also there was no argument. The researcher wrote the following in his diary (RD3):

"I had fun as much as the children because the activity worked out as I planned. The students started to work in harmony in-group work. Even though they work with different students in activities, they mostly get along with each other. They did not want to go on a break because they moved around during the games, so we continued the games. They had so much fun during this game because they got three turns instead of one."

\section{Comments on game-based activities}

Students were asked to write down their feelings, thoughts and decision making about the game-based activities in their diaries. All of the students stated that they had fun and enjoyed the activities, understood and learnt the topics, had a fast and good learning process, gained various cognitive, emotional and psychomotor skills, and sometimes even prepared for exams with games. They also said that they collectively decided as a group. Here are some examples of students' answers:

Eda: It helps us learn and develop strategies.

Arda: It was great and so fun, the competition was so fun.

Ayça: It was great. It develops our skills. We made decisions by taking everyone's opinion.

Metin: I loved it very much. It was so fun. It teaches us certain things. It improves our thinking skills.

Güray: It helps us to focus.

Emre: It improves us; we learn by playing games, it even prepares us for the exams.

Elçin: I learn better and faster because the games are enjoyable. We made decisions by voting.

Emel: It improves our Turkish, also we exercise our brain and it strengthens our hand muscles.

Beren: I liked it very much. We learn and have fun. Everybody shared what they thought, explained their reasons and we tried to find the right answer, at the end we shared our decision.

Kemal: The games were great and enjoyable. They help us learn. I played golf for the first time.

According to the activities covered in this study, it can be said that the activities based on games contribute to observing students' deficiencies related to the subject and increase of their success. It also shows them having fun, student participation, students being active, increase of interest, attention and motivation, the development of social skills and relations. It is also suitable for individual differences, supports uninterested and disadvantaged students from various angles, helps them participate in in-out class activities, it gives students immediate feedback and makes class management easier, so it provides important contributions to the teaching-learning process.

\section{DISCUSSION}

In this study, various results were obtained within the scope of digital story preparing and game-based activities.

First, this study was prepared according to the FCM; students had the opportunity to revise until they understood the topic completely while completing e-learning content on the internet at home. The content could be accessed from anywhere without the limit of 
time and space. In the context of the Turkish course, the texts (reading, listening, watching etc.) that consume time in the classroom and warm-up activities based on the text are completed at home. In the classroom, there is a considerable time gap for short or long activities based on practice. The activities presented in this study were carried out in three hours covering one or more than one topic and learning outcome. Therefore, the systematic pattern of the FCM combining in-out class teaching-learning processes allows for active, highly efficient, interactive activities. Studies also support the results of the research. Studies in literature support this study in terms of the effectiveness of the model and the positive results on students' satisfaction (Alsancak, 2015; Alsancak Sırakaya, 2017; Ayçiçek \& Yanpar Yelken, 2018; Cabi, 2018; Chen, Wang \& Chen, 2014; Çakır \& Yaman, 2018; Enfield, 2013; Günay Ceylaner \& Karakuș , 2018; Hung, 2015; Hurley, 2014; Tütüncü \& Aksu, 2018; Ünsal, 2018; Zeren, 2016).

In addition to the imagination and creativity of the students, the motor and technology skills were demonstrated in the digital story preparation activity. Particularly, it can be considered that the families have developed positive thoughts as witnesses to students recreating scenes with playdough, recording their voice and sending them to the researcher with the help of technology. In addition, there is a variety of development in some students which were in the problematic and disadvantaged groups. The fact that these students actively participated in this activity while they were not interested, distracted, had problems with focus, had low level of participation, didn't want to join activities or raise their hands before can be accepted as an indicator that the activity of digital story preparation is appropriate for students at all levels. So, it can be said that it supports students having fun while learning, their participation, language skills, imagination, technology literacy, social, effective communication and motor skills.

These results are the same as the results of the studies related to the language teaching lessons in particular. The studies emphasize that digital stories make lessons enjoyable and productive, affect the improvement of language skills, interest, attitudes, attention and motivation in a positive way (Abdollahpour \& Asaszadeh, 2012; Akın \& Çeçen, 2015; Ciğerci, 2015; Demirer, 2013; Kahraman, 2013; Ohler, 2006; Salkhord, Gorjian \& Pazhakh, 2013).

Game-based activities in the context of the Turkish course were prepared in accordance with the texts, basic language skills, vocabulary teaching and language skills. The straw game was prepared for reviewing the text and teaching vocabulary, Jenga for teaching grammar, and golf for reading comprehension skills. At the same time, it can be said that such activities can be used on each stage (warm-up, teaching-learning process and evaluation). Besides, it can be said that games do not have to be based on competition or rewards. Because it was observed, that Jenga in particular raised the attention and motivation of 'game' students depending on their age group and developmental periods. Within this context, it can be said that minor changes to the teaching-learning processes for the students, and especially activities involving games, can bring many benefits. The learning outcomes resemble the results of the studies in the literature (Alsancak Sirakaya, 2017; Glover, 2013; Hanus \& Fox, 2015; Muntean, 2011; Touchton, 2015; Y1ldırım \& Demir, 2016). 
Behaviors interrupting the lesson and games such as noise and cheering diminish gradually by using game-based activities actively and frequently during learningteaching processes. Therefore, the students learn and have fun at the same time. This situation turns into a new game and activity culture that has its own dynamics.

It should not be forgotten that activities that all the students participate in and each student enjoy take time. However, with the gradual decrease in classroom management and behavioral problems, it should be kept in mind that students learn by having fun. Their emotional ties to the school and the teacher strengthen, the lessons always arouse curiosity, and the students do not even want to have a break. That is why many learning outcomes can be achieved in a short time.

\section{CONCLUSION AND RECOMMENDATION}

In conclusion, with the use of FCM, by enriching with digital story and game-based activities teaching-learning processes in Turkish courses, the development of students in many areas, firstly basic language skills, then cognitive, emotional, social and psychomotor skills were contributed. The students and their parents had positive comments and views about the activities.

According to the results achieved within this context, teachers can be recommended to design digital story preparation or game-based activities for almost every lesson and subject. Additionally, according to the age and developmental periods of the students, the instructions about how to perform the activity, how to play the game or how to behave for the classroom management should be as detailed as possible. Also, the process should be described in detail to the parents and their role in this process should be explained clearly. The students should be given plenty of time to study freely and comfortably. During the activities, the questions of the students, except the general ones, should be dealt with one to one. Researchers can design a variety of game-based educational digital or in-class games, and can carry out studies by seeing their effects and processes in different contexts.

\section{REFERENCES}

Abdollahpour, Z. \& Asaszadeh, N. (2012). The impact of exposure to digital flash stories on Iranian EFL learners' written reproduction of short stories. Canadian Journal on Scientific and Industrial Research, 3(2), 40-53.

Akın, E. \& Çeçen, M. A. (2015). Çoklu ortama dayalı Türkçe öğretimine ve çoklu ortam araçlarına yönelik öğrenci görüşleri. Turkish Studies, 10(7), 51-72. http://dx.doi.org/10.7827/TurkishStudies.8229.

Alsancak Sırakaya, D. (2017). Oyunlaştırılmış Tersyüz Sınıf Modeline yönelik öğrenci görüşleri. Ondokuz Mayıs Üniversitesi Eğitim Fakültesi Dergisi, 36(1), 114-132. Retrieved from http://dergipark.gov.tr/omuefd/issue/30333/327393.

Alsancak, S. D. (2015). Ters yüz sınıf modelinin akademik başarl, öz yönetimli öğrenme hazırbulunuşluğu ve motivasyon üzerine etkisi. (Yayımlanmamış Doktora Tezi). Gazi Üniversitesi, Ankara. 
Ayçiçek, B., \& Yanpar Yelken, T. (2018). The effect of Flipped Classroom Model on students' classroom engagement in teaching English. International Journal of Instruction, 11(2), 385-398. https://doi.org/10.12973/iji.2018.11226a.

Barrett, H. (2005). Researching and evaluating digital storytelling as a deep learning tool. Retrieved from http://electronicportfolios.org/portfolios/SITEStorytelling2006.pdf.

Başal, A. (2012). The use of flipped classroom in foreign language teaching. The 3rd Black Sea ELT Conference "Technology: A Bridge to Language Learning", November 15-17, 2012, Samsun, Turkey.

Basal, A. (2015). The implementation of a Flipped Classroom in foreign language teaching. Turkish Online Journal of Distance Education, 16(4), 28-37.

Bergmann, J. \& Sams, A. (2012). Flip your classroom: Reach every student in every class every day. Washington, DC: International Society for Technology in Education.

Bergmann, J. \& Sams, A. (2014). Flipped learning: Gateway to student engagement. Washington, DC: International Society for Technology in Education.

Bishop, J. L. \& Verleger, M. A. (2013). The flipped classroom: A Survey of the research. 120th ASEE Annual Conference \& Exposition (pp. 1-18). Atlanta, GA: ASEE.

Cabi, E. (2018). The impact of the Flipped Classroom Model on students' academic achievement. The International Review Of Research In Open And Distributed Learning, 19(3). doi:http://dx.doi.org/10.19173/irrodl.v19i3.3482

Çakir, E., \& Yaman, S. (2018). Ters Yüz Sınıf Modelinin öğrencilerin fen başarısı ve bilgisayarca düşünme becerileri üzerine etkisi. Gazi University Journal of Gazi Educational Faculty (GUJGEF), 38(1), 75-99. Retrieved from http://www.gefad.gazi.edu.tr/issue/36713/342857.

Chen, Y., Wang, Y., \& Chen, N. S. (2014). Is FLIP enough? Or should we use the FLIPPED model instead? Computers \& Education, 79, 16-27. https://doi.org/10.1016/j.compedu.2014.07.004.

Ciğerci, F. M. (2015). Illkokul dördüncü sınıf Türkçe dersinde dinleme becerilerinin geliştirilmesinde dijital hikâyelerin kullanılması. Yayınlanmamış Doktora Tezi. Anadolu Üniversitesi, Eskişehir.

Cockrum, T. (2017). Emerging models of practice in Flipped English language arts classrooms. In Applying the Flipped Classroom Model to English Language Arts Education (C. A. Young \& C. M. Moran, Eds.) (pp. 160-176). IGI Global.

Demirer, V. (2013). Illköğretimde e-öyküleme kullanımı ve etkileri. Yayınlanmamış Doktora Tezi. Necmettin Erbakan Üniversitesi, Konya.

Di Bitonto P., Corriero N., Pesare E., Rossano V., \& Roselli T. (2014) Training and learning in e-health using the gamification approach: The trainer interaction. Stephanidis 
C., Antona M. (eds.) Universal access in human-computer interaction: Aging and assistive environment, Lecture Notes in Computer Science, vol 8515. Springer, Cham.

Dupain, M. \& Maguire, L. (2005). Digital story books projects 101: How to create and implement digital storytelling into your classroom. Proceeding in "21st Annual Conference on Distance Teaching and Learning".

Ekiz, D. (2009). Bilimsel araştırma yöntemleri. Ankara: Anı.

Ekmekçi, E. (2017). The Flipped writing classroom in Turkish EFL context: A comparative study on a new model. Turkish Online Journal of Distance Education, 18(2), 151-167.

Enfield, J. (2013). Looking at the impact of the flipped classroom model of instruction on undergraduate multimedia students at CSUN. Techtrends: Linking Research \& Practice to Improve Learning, 57(6), 14-27.https://doi.org/10.1007/s11528-013-0698-1.

Fulton, K. (2012). Upside down and inside out: Flip your classroom to improve student learning. Learning \& Leading with Technology, 39(8), 12-17.

Gençer, B. G., Gürbulak, N. \& Adıgüzel, T. (2014). Eğitimde yeni bir süreç: Ters-yüz sinıf sistemi. Uluslararası Öğretmen Eğitimi Konferansı. 5-6 Şubat 2014. Dubai.

Glover, I. (2013). Play as you learn: gamification as a technique for motivating learners. Proceeding in "World Conference on Educational Multimedia, Hypermedia and Telecommunications". Chesapeake, VA, AACE.

Günay Ceylaner, S., \& Karakuș F. (2018). Effects of the Flipped Classroom Model on students' self-directed learning readiness and attitudes towards the English course. English Language Teaching, 11(9), 129-143. DOI: 10.5539/elt.v11n9p129.

Güneş, F. (2012). Testlerden etkinliklere Türkçe öğretimi. Dil ve Edebiyat Eğitimi Dergisi, 1(1), 31-42.

Hanus, M. D., \& Fox, J. (2015). Assessing the effects of gamification in the classroom: A longitudinal study on intrinsic motivation, social comparison, satisfaction, effort, and academic performance. Computers \& Education, 80, 152-161. http://psycnet.apa.org/doi/10.1016/j.compedu.2014.08.019.

Herreid, C. F., \& Schiller, N. A. (2013). Case Studies and the Flipped Classroom. Journal of College Science Teaching, 42(5), 62-67. Retrieved from http://www.jstor.org/stable/43631584.

Hung, H. (2015). Flipping the classroom for English language learners to foster active learning. Computer Assisted Language Learning, 28(1), 81-96. https://doi.org/10.1080/09588221.2014.967701.

Hurley, K. S. (2014). A case study of learner and instructor perceptions of flipped course design and interactive learning environment, International Journal Social Media 
and Interactive Learning Environments, 2(4), 361-377. https://doi.org/10.1504/IJSMILE.2014.067642.

Kahraman, Ö. (2013). Dijital hikâyecilik metoduyla hazırlanan öğretim materyallerinin ögrrenme döngüsü giriş aşamasında kullanılmasının fizik dersi başarısı ve motivasyonu düzeyine etkisi. Yayınlanmamış Doktora Tezi. Balıkesir Üniversitesi, Balıkesir.

Karadeniz, A. (2015). Ters-yüz edilmiş sınıflar. Ĕgitim ve Öğretim Araştırmaları Dergisi (Journal of Research in Education and Teaching), 4(3), 322-326. Retrieved from http://www.jret.org/FileUpload/ks281142/File/35._abdulkadir_karadeniz.pdf.

Kirk, J., \& Miller, M. L. (1986). Reliability and validity in qualitative research. Beverly Hills, Ca.: Sage.

LaFee, S. (2013). Flipped learning, Education Digest, 79(3), 13-18. Retrieved from https://search.proquest.com/docview/1449599156?accountid=16716.

Matthews, G. (2008). Digital storytelling tips and resources. Boston: Simmons College.

Meadows, D. (2003). Digital storytelling: Research-based practice in new media. Visual Communication, 2(2), 189-193. http://dx.doi.org/10.1177/1470357203002002004.

Mills, G. E. (2003). Action research: A guide for the teacher researcher. New Jersey: Prentice-Hall.

Moran, C. M. (2014). Changing paradigms: A mixed methods study of flipping the English language arts classroom. Unpublished Doctoral Dissertation, North Carolina State University.

Moran, C. M. (2018). “Just Don't Bore Us to Death": Seventh graders' perceptions of flipping a technology-mediated English language arts unit. Middle Grades Review, 4(1), $1-17$.

Muntean, C. I. (2011). Raising engagement in e-learning through gamification. Proceeding in "6th International Conference on Virtual Learning”, Romania.

Ohler, J. (2006). The world of digital storytelling. Educational Leadership, 63(4),44-47.

Oral, B. (2005). İnternet ve eğitim. Internet ve toplum içinde, 90-116.

Oral, Ş. (2014). Müzikli masal sepeti-2. İstanbul: Kelime.

Pasisis, G. (2015). The flipped reading block: Making it work. New York: Scholastic.

Prashar, A. (2015) Assessing the Flipped Classroom in operations management: A pilot study. Journal of Education for Business, 90(3), 126-138. https://doi.org/10.1080/08832323.2015.1007904.

Salkhord, S., Gorjian, B. \& Pazhakh, A. (2013). The effect of digital stories on reading comprehension: An internet-based instruction for Iranian EFL young learners. International Journal of Language Learning and Applied Linguistic World,4(4),11-124. 
Sarıtaş, M. T. ve Yıldız, Ö. (2015). Eğitimde oyunlaştırma ve ters-yüz sinıflar. Proceeding in "Akademik Bilişim Konferansı 2015”. Anadolu University, Turkey.

Sawyer, C. B., and Willis, J. M. (2011). Introducing digital storytelling to influence the behavior of children and adolescents. Journal of Creativity in Mental Health, 6, 274283. https://doi.org/10.1080/15401383.2011.630308.

Seaborn, K., \& Fels, D. I. (2015). Gamification in theory and action: A survey. International Journal of human-computer studies, 74, 14-31. https://doi.org/10.1016/j.ijhcs.2014.09.006.

Sever, S. (2011). Türkçe öğretimi ve tam öğrenme. Ankara: Anı.

Smeda, N., Dakich, E., \& Sharda, N. (2012). Digital storytelling with Web 2.0 tools for collaborative learning. In A. Okada, T. Connolly, \& P. Scott (ed.), Collaborative learning 2.0: Open educational resources. 145-163. Hershey: IGI Global.

Su, C. H., \& Cheng, C. H. (2015), A mobile gamification learning system for improving the learning motivation and achievements. Journal of Computer Assisted Learning, 31(3), 268-286. https://doi.org/10.1111/jcal.12088.

Temizyürek, F. ve Ünlü, N. A. (2015). Dil öğretiminde teknolojinin materyal olarak kullanımına bir örnek: "Flipped classroom". Bartın Üniversitesi Ĕgitim Fakültesi Dergisi, 4(1), 64-72.

Touchton, M. (2015). Flipping the classroom and student performance in advanced statistics: Evidence from a quasi-experiment. Journal of Political Science Education, 11(1), 28-44. https://doi.org/10.1080/15512169.2014.985105.

Tütüncü, N. \& Aksu, M. (2018). A systematic review of flipped classroom studies in Turkish education. International Journal of Social Sciences and Education Research, 4(2), 207-229.

Ünsal, H. (2018). Ters yüz öğrenme ve bazı uygulama modelleri. Gazi Eğitim Bilimleri Dergisi, 4(2), 39-50. Retrieved from http://dergipark.gov.tr/gebd/issue/38655/437492.

Urfa, M. (2018). Flipped Classroom Model and practical suggestions. Journal of Educational Technology \& Online Learning, 1(1), 47-59.

Yıldırım, A. \& Şimşek, H. (2008). Sosyal bilimlerde nitel araştırma yöntemleri. Ankara: Seçkin.

Yıldırım, İ. \& Demir, S. (2016). Oyunlaştırma temelli “öğretim ilke ve yöntemleri” dersi öğretim programı hakkında öğrenci görüşleri. International Journal of Curriculum and Instructional Studies, 6(11), 85-101.

Zeren, M. G. (2016). The flipped geography lecture. Marmara Coğrafya Dergisi, 33, 25-57. http://dx.doi.org/10.14781/mcd.79389. 